\title{
Improving Metropolitan Government : the Case of Manila
}

\section{J. Davies}

"An integrated rational organisation is the exception rather than the rule in most metropolitan areas. Meanwhile, the difficulties accumulate to such an extent that the problems can no longer be ignored, and a solution cannot be postponed indefinitely. The fundamental question is therefore what kind of solution will sooner or later be adopted".

\section{W. A. Robson: Great Cities of the World ${ }^{1}$}

The difficulties referred to by Robson are the economic, social and physical problems caused by the spread of cities. In many of the world's largest urban areas, the consequences of rapid population growth, an expanding metropolitan area and haphazard or minimal land-use planning, pose a range of problems which are intractable, often highly visible, and touch the lives of all who live and work in the metropolis.

Despite the compelling nature of these metropolitan problems, government organisations with the unenviable task of attempting to resolve them tend to be fragmented. The responsibility for providing services, the authority to monitor and control the activities of local organisations, and the power to levy rates and taxes, may well be divided amongst a number of local and national authorities and agencies. Given the multiplicity of these organisations, it is not uncommon for emphasis to be given to protecting an authority's autonomy, to maintaining role and status, and to preserving traditional responsibilities and activities. The end result within the metropolis may be that scarce resources are dissipated and piecemeal solutions attempted, rather than attention being directed to the needs of the urban area as a whole.

Robson took the view that the particular nature and increasing intensity of urban problems would inevitably force national governments to re-examine the structures of metropolitan governments in an effort to secure improvements in the scope and quality of urban services. Although a new pattern of local government in urban areas

\footnotetext{
1 This paper is based on a study of metropolitan reform undertaken in the Philippines in 1977/78. under the auspices of the Ministry of Overseas Development's Teaching Materials Collection Programme. The research report. Restructing the Metropolis: The Case of Manila was published by the Development Administration Group as Occasional Papers in Development Administration, No. 4 in 1978 .
}

is not a sufficient condition for improved urban management-for example, changes in the structure and process of management within the local authority might be also required-in many metropolitan areas, inter-authority reform has preceded intra-authority reform. However, if Robson's view of the inevitability of metropolitan reform is correct, and the reports of urban reform exercises from around the world seem to support such a view, two major questions must be asked. First, what types of structure are available as a basis or model for metropolitan reform, and which of these alternative structures is to be preferred? Second, to what extent can one predict the outcome of any preferred alternative, that is in terms of its capacity to provide a system of improved area management?

\section{Alternatives for metropolitan reform}

A variety of structural forms could be taken as the basic framework for the area-wide management of a metropolis. If the general pattern of local government for a metropolitan area is assumed to be a group of relatively small authorities, each with a similar set of powers and responsibilities, alternative structures can then be classified on the basis of the extent to which they represent a change from this existing pattern.

As far as the Third World metropolitan regions are concerned, Barbara Ward provides strong support for the view that level 5 , a single-tier multi-purpose authority, is the most appropriate local government structure (Ward, 1976: 23444). Given that such an authority would have area-wide responsibilities, and possess adequate financial and managerial resources, it can well be argued that the key tasks of identifying community needs, determining goals to meet those needs, coordinating the use of resources to achieve the goals, and monitoring and reviewing service delivery, can best obtain in the singletier, area-wide form of metropolitan government.

However, two major factors may constrain the successful establishment of a unitary system of metropolitan government. The first is the political environment. No matter how overwhelming the need for an area-wide, single-tier structure of government, or how strong the concern of the central government to introduce such a system, the subsequent reform has often been either limited in its effect, because of pressure from 


Minimal
$\begin{aligned} & \text { Change } \\ & \text { Level } \\ & \text { 1. Existing Authorities Continue. } \\ & \text { Informal cooperative mechanisms } \\ & \text { are established. } \\ & \text { Existing Authorities Continue. } \\ & \text { A formal coordinating structure } \\ & \text { is established. } \\ & \text { A two-tier system of Authorities is created. } \\ & \text { The principal City/Municipality is extended, } \\ & \text { This provides single-tier government for } \\ & \text { the whole metropolitan area. } \\ & \text { A new single-tier multi-purpose Authority } \\ & \text { is created. This replaces the existing } \\ & \text { group of Authorities. } \\ & \text { A group of new single-purpose } \\ & \text { 1. }\end{aligned}$
$\begin{aligned} & \text { Authorities is established. These } \\ & \text { replace the existing Authorities. }\end{aligned}$
6.

dominant social or economic groups, or reduced in scope, through the intervention of entrenched political interests. Leemans, Robson, and Walsh have each outlined the important part played by political groups in the process by which metropolitan government reforms have been accepted and established. (Leemans, 1970: 165; Robson, 1972: 77; Walsh 1969: 81).

The second major constraint on the adoption of the unitary solution is that the sheer size of the conurbation, in terms of geographical area as well as population, may generate problems beyond the managerial capacity of a unitary authority, and may also complicate current methods of local participation and local democracy. This was the conclusion of the Royal Commission on Local Government in England, which considered that a unitary structure of local government was not appropriate for urban areas with a population substantially more than a million (HMSO 1969: para. 278). Although such 'diseconomies of scale' could to some extent be resolved by schemes of area management within the urban authority, they may be seen by many central governments as a sufficient reason for adopting a two-tier structure to administer a country's largest metropolitan areas.

Evidence from the two major comparative urban studies undertaken in recent years, would seem to confirm the choice of a two-tier structure. Of the 13 cities examined in the Walsh study, 11 had some form of two-tier structure, and only two had a single, consolidated form of metropolitan government. The Robson study indicated that only seven of the 27 cities examined could be described as having a single-tier structure of government.

If the preferred structure for a metropolis is a two-tier arrangement, a variety of relationships can exist between the tiers. These can be shown on a linear scale, the polar opposites being a hierarchical, two-tier structure, and a federal, two-level, structure. Any particular proposal for the reform of metropolitan government which involves an arrangement of tiers can be seen to tend towards one or other polar extreme:

\begin{tabular}{|c|c|c|}
\hline Hierarchical & & Federal \\
\hline Structure & & Structure \\
\hline $\begin{array}{l}\text { The lower levels of } \\
\text { government will be } \\
\text { responsible to, and } \\
\text { controlled by the } \\
\text { higher level of } \\
\text { government. }\end{array}$ & $\bullet$ & $\begin{array}{l}\text { The two levels of } \\
\text { government will each } \\
\text { have separate } \\
\text { responsibilities and } \\
\text { financial resources. }\end{array}$ \\
\hline
\end{tabular}


When reform proposals for a metropolitan area are under consideration, there are three variables which are an important focus of attention: the geographical area of the various tiers; the responsibilities to be given to each level of government; and the 'mix' of federal autonomy and hierarchical control to be enjoyed by each type of authority. Consequently, the nature of the suggested reforms will depend upon how the proposers have ranked the following set of factors, and the weight they have assigned to each factor.

\section{Democratic factors}

Local democracy

(There is no stipulative definition of local democracy, and individuals or groups who are considering government reform may interpret the concept in different ways, and variations in the recommended pattern of local government areas and the allocation of responsibilities may result.)

\section{Political factors}

Political and administrative history

Current political realities

Central control of local authorities

3. Administrative and financial factors

Appropriate personnel and management structures

Viable financial resources

Population structure and distribution

The functional requirements of local services (For example, 'catchment areas' for particular services, expressed in terms of clientele or geography; see Davies, 1973; Bristow, 1972; Leemans, 1970: 17-27).

These factors are not complementary and many conflict, in the sense that the application of different factors would lead to the establishment of different territorial patterns. It follows that each factor, or group factors, may be consistent with a quite different pattern of areas and different set of responsibilities. Consequently, the particular pattern of local authority areas, and the distribution of functions between the tiers suggested in a reform proposal, will reflect the importance which has been assigned to one factor, or group of factors. That is, there can be no 'correct' structure of metropolitan government in any strict sense. When evaluating a proposal for reform, consideration must be given not only to the way in which the factors have been weighted and ranked, but also the extent to which the outcome-the recommended structure of metropolitan government-is consistent with the requirements of the factors, and is capable of supporting an improved system of area management.

In order to illustrate this form of analysis, the reorganisation of local government in metropolitan Manila may be taken as an example.

Improving area management: the reform of government in Greater Manila

During the $1960 \mathrm{~s}$, the increasing pressure of urban problems in the greater Manila area was such as to provide strong support for Robson's proposition that there could be no indefinite postponement of metropolitan reform. These problems included environmental pollution, flooding, road congestion, and the consequences of unsatisfactory land-use. In addition many residents-perhaps the majority-were forced to contend with a set of much more personal problems which followed from imbalances in the provision of services. These included minimal employment opportunities, a lack of housing and shelter facilities, difficulties stemming from the limited provision of public utilities, and the absence of satisfactory health and welfare services. The range and scope of these problems in the urban area had long been recognised, and methods of resolving such difficulties were the common coinage of discussion among official bodies, private groups, academics and the media during the 1960 s and early 1970s. Included in these discussions was the question of the structural reform of local government for Greater Manila. Within the area, the provision of local services was the responsibility of 28 local government units, each with a similar set of powers and responsibilities, and each concerned with the delivery of services only in its own area.

In the years in which local government reform was under discussion, more than a dozen alternative reform structures were suggested, involving some or all of the existing local government units. On the basis of the above typology, an indication of the range of these recommendations can be given:

\section{Level 1. Minimal change}

This reform proposal related only to the four Cities and ten Municipalities which formed the inner core of the metropolitan area. Little alteration to the existing pattern and responsibilities of these local government units was envisaged. The major recommendation was aimed at 
improving coordination between the 14 authorities through the establishment of a Coordinating Council for Metropolitan Manila, to be composed of the Mayors of the 14 local government units. Responsibility for service delivery, however, would remain with each City and Municipality.

\section{Level 5. Maximum change}

This proposal was concerned with the reform of local government throughout the area of Greater Manila. The major recommendation was that a Public Corporation be established, the Manila Capital District, to be responsible for both the planning and delivery of local services throughout the area. The existing 28 local authorities would thus be abolished, and their responsibility for service provision would pass to the Manila Capital District.

The culmination of these discussions was the acceptance by the Marcos Government of a measure of metropolitan reform and the intention to reorganise local government in Manila received popular approval in the referendum which was held in February 1975. The new structure of government for the metropolitan area was promulgated in the form of a Presidential Decree in November 1975, taking immediate effect.

\section{Structural and manageral reforms}

The Decree provided for the creation of a twotier structure of government for the central area of Greater Manila, which had previously been administered by 17 local government units. ${ }^{2}$ A public corporation, the Metropolitan Manila, was to form the top tier of the new local government system. The Corporation was given broad sets of responsibilities: the first was concerned with the planning and implementation of certain common services throughout the area as a whole. The second set of responsibilities gave the Corporation control and review powers over the second-tier local authorities. The existing City and Municipal authorities would therefore continue to be responsible for the provision of a range of services within their areas. However, these services would be provided only with the approval, or at the direction of the governing body for the area as a whole, that is, the Metropolitan Manila Commission.

The newly established Corporation was to be administered by a five-member Commission. This

2 The local government units werc as follows:

cities: Manila. Caloocan. Pasay. Quezon City:

municipalities: Makati. Mandaluyong. San Juan. Las

Pinas. Malabon. Navotas. Pasig. Pateros. Paranaque.

Marikina. Muntinglupa. Taguig. Valenzuela. was to be composed of a Chairman, Vice-Chairman and three Commissioners, appointed by the President and responsible to him. The Commission would have a dual role: to formulate policy for certain area-wide services; and to manage the provision of these services, in that the Chairman and Vice-Chairman of the Commission would also be the Manager and Deputy General Manager of the Corporation, and thus have executive responsibility for the government of Metropolitan Manila. Apart from its responsibilities in providing common services, the Corporation was given powers to coordinate, to monitor and review, and to initiate action over a broad range of activities undertaken by local government authorities and private agencies in the metropolitan area. The organisation of the Metropolitan Manila Commission was as follows:

The Metropolitan Manila Commission

Chairman and Manager

Vice-Chairman and Deputy General Manager

Commissioner for Finance

Commissioner for Planning

Commissioner for Operations

Fire Control Operations Centre

Garbage Disposal Operations Centre

Transport and Traffic Centre

The Commission was also required to

coordinate, monitor and initiate activities in

relation to:

Transportation;

Flood control and drainage;

Water supply and sewerage;

Social, health, and environmental services;

Housing;

Park development;

Barangay participation.

Source: Presidential Decree No. 824, November 1975.

The new structure of metropolitan government for Manila was, of course, a compromise solution, and owed much to the discussions, reports and proposals which preceded the reform. However, it was clear that an attempt had been made to resolve what were seen to be the most pressing problems facing the metropolis. Thus difficulties which in the past had stemmed from the absence of any government organisation or agency responsible for area-wide metropolitan concerns, were resolved by the creation of a top-tier authority. The pre-disposition of the existing local authorities against cooperation was countered by giving the Metropolitan Manila Commission wide-ranging powers of control and direction over public and private bodies operating 
in the urban area. The possibility of delay and conflict in the planning and delivery of services, which might have occurred through pressures stemming from the overlapping power centres inherent in the 'separation of powers' system of government in the Philippines, was avoided through the device of a public corporation, headed by a Presidential appointee. Although local councils in the metropolitan area would in future have a restricted role, the effort was made to provide an opportunity for traditional political groups to play a part in the government process, through the continuation of the offices of Mayors and Councillors in the second-tier local authorities.

Although these would seem to be clear benefits stemming from the new government structure, attention must be given to its capacity to support and enhance an improved system of management, in terms of identifying community needs, and providing a range of services to meet those needs. Thus it becomes necessary to examine the factors which determined the final shape of the new government structure for metropolitan Manila, and assess the extent to which it may be appropriate for the management of a rapidly growing urban area.

\section{Conclusion}

If the framework of analysis set out above was to be applied to government reform in metropolitan Manila, the conclusion would appear to be that political factors were the major determinants. Thus there was little change in the existing pattern of political units: the traditional City and Municipality boundaries were not altered, and the boundary of the new Metropolitan Manila Commission was drawn relatively tightly around the 'inner core' of authorities with little opportunity or scope for extending its area. As far as the structure and powers of the Commission were concerned, both the hierarchical pattern of allegiance to the central government, and the new 'dependency' relationships of the constituent local units to the Commission, are a fair reflection of the political changes being introduced at the national level: the replacement of the American 'separation of powers' political structure, by the British 'winner takes all' system of a combined legislature and executive. Given the undoubted importance of politics and the political process in Philippine society, with pyramids of leaders and followers as the building blocks of the political structure, the final shape of the new metropolitan government for Manila could be said to be fairly predictable.
Although important, it is questionable whether the political factors should be taken as crucial by those determining the final shape of metropolitan structures, and which in Manila limited the degree of change from the existing traditional pattern of local government. Given the type and scale of the urban problems which were paramount in Manila, it may be argued that the administrative and financial factors of service provision should have been a more appropriate focus of concern. It may be suggested that the key determinant of structural reform in the metropolitan area should not have been political considerations, but the requirements for service delivery and the availability and adequacy of resources to meet the needs of client groups. The most important problems facing the majority of residents in Manila may have a dual source: the interlocking needs of disadvantaged and deprived groups, and the variations which exist between the local authorities in the level of their financial resources and the adequacy and scope of their service provision.

Consequently, if the reform focus in Manila had been on service requirements, access to service delivery by local inhabitants, and equity of financial resources between authorities, a quite radical pattern of local authorities might well have emerged, cutting across the traditional political boundaries. An example of such a structure using population distribution and expenditure resources as the basis of regrouping, has been suggested by the Local Government Centre of the University of the Philippines (de Guzman, 1975). In this structure the 17 local government authorities which together form the inner metropolitan area have been grouped into six districts.

Even under this new arrangement, there are still major differences between the groups, but the change in the structural pattern which may occur from the application of criteria other than political factors is clearly illustrated. In addition to an alteration in the pattern of authorities, a change in the factors determining a new structure of local government might also have had consequences for the role of the Metropolitan Manila Commission. For example, an initial focus on problems of service delivery might have resulted in an emphasis on the role of the Commission in creating employment opportunities, or in the provision of welfare services. Consideration may also have been given to providing powers and responsibilities to the Commission which would have enabled it to play a major role in the attack upon deprivation and 


\begin{tabular}{|c|c|c|c|}
\hline District & $\begin{array}{c}\text { Population } \\
1970\end{array}$ & $\begin{array}{l}\text { Total Available } \\
\text { Income for } \\
\text { Expenditure } \\
\text { (Pesos '000) }\end{array}$ & $\begin{array}{c}\text { Total Available } \\
\text { Income for } \\
\text { Expenditure } \\
\text { (Pesos per Capita) }\end{array}$ \\
\hline I Manila & $1,330,700$ & 206,532 & 155 \\
\hline $\begin{array}{l}\text { II Caloocan } \\
\text { Navotas } \\
\text { Malabon } \\
\text { Valenzuela }\end{array}$ & 598,000 & 43,693 & 73 \\
\hline III Quezon City & 754,000 & 79,306 & 105 \\
\hline $\begin{array}{l}\text { IV Marikina } \\
\text { Pasig } \\
\text { Mandaluyong } \\
\text { San Juan }\end{array}$ & 524,000 & 47,466 & 90 \\
\hline $\begin{array}{c}\text { V Makati } \\
\text { Pateros } \\
\text { Taguig }\end{array}$ & 346,000 & 82,354 & 238 \\
\hline $\begin{array}{l}\text { VI Pasay } \\
\text { Paranaque } \\
\text { Las Pinas } \\
\text { Muntinglupa }\end{array}$ & 414,000 & 38,334 & 92 \\
\hline
\end{tabular}

hardship, a feature of life for many families in the metropolis.

As it is, the new structure of metropolitan government in Manila may, in retrospect, be seen as only a partial solution to the area's problems. The need for the provision of basic municipal services on an area-wide basis, and the acceptance, in political terms, of these changes may well have been achieved. But other, major questions, involving the scope and scale of service provision, and access to those services by the disadvantaged, appear to have been left untouched. These problems may, in the future, have further structural consequences for the government of metropolitan Manila.

\section{References}

Bristow, S. L., 1972, The Criteria for Local Government Reorganişation and Local Authority Autonomy, Policy and Politics, vol. I, Macmillan, London

Davies, C. J., 1973, The Reform of Local Government with special reference to England,
Studies in Comparative Local Government, vol. 7, IULA, The Hague

de Guzman, R. P., 1975, Alternatives for Metropolitan Governance, Local Government Bulletin, Local Government Centre, University of the Philippines, Manila

HMSO, 1969, Royal Commission on Local Government in England 1966-69, vol. 1, Cmnd. 4040, London

Leemans, A. F., 1970, Changing Patterns of Local Government, IULA, The Hague

Robson, W. A. and D. E. Regan, 1972, Great Cities of the World, George Allen and Unwin, London

Walsh, A. H., 1969, The Urban Challenge to Government, Praeger, New York

Ward, B., 1976, The Home of Man, Andre Deutsch, London 